\title{
The Effect of Work Communication and Work Motivation to Employee Performance at PT. Catur Mitra Sejati Sentosa
}

\author{
Miftachul Choir, Elok Damayanti, Joko Suyono \\ Narotama University, Faculty of Economics and Business, Surabaya, Indonesia \\ miftachulchoir95@gmail.com, elok.damayanti@narotama.ac.id, \\ joko.suyono@narotama.ac.id
}

\begin{abstract}
This research intends to determine: (1) the effect of work communication on employee performance, and (2) the effect of work motivation on employee performance. The population in this research are all employees of PT. Catur Mitra Sejati Sentosa, totaling 65 employees. The sample utilized in this research is the entire population of 65 employees, thus it is called a population research. Instrument testing was carried out at PT. Catur Mitra Sejati Sentosa. The validity test used correlation product moment, while the reliability test used Spearman Brown which processed by using SPSS 18.0 for Windows. In the validity test of work communication, there are 9 statements and all are valid. In the validity test of work motivation, there are 5 statements and all are valid. In the validity test of employee performance, there are 9 statements and all are valid. Furthermore, the classical assumption test includes multicollinearity test and heteroscedasticity test. Meanwhile, the hypothesis test in this research applies multiple regression analysis and the coefficient of determination. The results of this research indicate that: (1) Work Communication (X1) has a partially significant influence on the Employee Performance variable $(\mathrm{Y})$. This is demonstrated by the magnitude of the significance value of 0.029 which is smaller than 0.05 . In accordance with these results, it can be concluded that work communication has a significant effect on the employee performance of PT. Catur Mitra Sejati Sentosa. (2) Work Motivation (X2) has a partially significant influence on Employee Performance (Y). This is indicated by the magnitude of the significance value of more than 0.008 which is smaller than 0.05 . According to these results, it can be inferred that work motivation has a significant effect on the employee performance of PT. Catur Mitra Sejati Sentosa. (3) Work Communication (X1) and Work Motivation (X2) have a significant effect simultaneously on the Employee Performance variable (Y). This is revealed by the magnitude of the significance value of more than 0.008 which is smaller than 0.05 . Based on these results, it can be concluded that work motivation has a significant effect on the employee performance of PT. Catur Mitra Sejati Sentosa. (3) Work Communication (X1) and Work Motivation (X2) have a significant effect simultaneously on the Employee Performance variable (Y).
\end{abstract}

Keywords:

Employee Performance, Work Communication, Work Motivation

\section{Introduction}

During the Covid-19 pandemic, the rapid competition required companies to develop new ideas in order to achieve company goals. The company must have advantages and competitiveness, so that it can survive among other companies. The role of human resources is essential in achieving company goals. According to Hasibuan (2002) human resources (HR) is the science and art of managing the relationships and roles of labor in order to make it effective and efficient in terms of realizing the company, employee and community goals. Especially in the retail business where many competing companies share strong goals and targets for advancing the company. For instance, PT. Catur Mitra Sejati Sentosa is a company that produces building materials located on Jalan Wiyung Surabaya. Located in the southern part of the Surabaya city, which is well-known for a lot of new housing developments. Selling building materials, especially granite and ceramics, with a variety of different services to the various prices, it caused this company has many competitors. Therefore, this company must be more nimble and clearer in carrying out all activities to achieve the main results and goals in accordance with the company's targets. In addition, employees with real and high performance are needed in advancing the company. According to Irham (2014), Performance is the result obtained by an organization, both profit oriented and non-profit oriented organization which is produced over a period of time.

Employee performance affects the success of PT. Catur Mitra Sejati Sentosa. While, the capability of a company to develop is rely on the competence of human resources. In order to utilize existing resources in the 
company to carry out work tasks within a purposeful framework. The success of all work tasks of a company is largely determined by the availability of quality human resources. This is not only about improving the quality of human resources, but the company is also required to continue to increase its competitiveness through improving the quality of management. Therefore, maintaining a harmonious and sustainable relationship with employees is essential so that the company can develop optimally. There are several negative factors that can lower employee performance, including poor communication with fellow employees and communication with consumers, and the lack of motivation to employees, thus employee productivity decreases. In this case, communication and motivation are highly important to achieve company goals.

Communication has a major role in organizational and group life. In light of achieving common goals, humans with a good communication organization are needed, communication can be either verbal or non-verbal, both of which can be used with the same goal of achieving company goals. In a company or organization, it is obligatory to teach excellent communication to all employees, hence, there will be no miscommunication either to fellow employees or to consumers. Meanwhile, at PT. Catur Mitra Sejati Sentosa, there are several obstacles in communication that affected to employee performance which is less good and also resulted in consumer complaints. Communication problems that often occur, are communication between divisions which caused consumer disappointment and eventually they complain. For examples, the wrong type of goods which taken or delivered to the consumers, and the incompatibility between the goods ordered and what the consumer receives. Communication, therefore, is an integral part of a management process through effective communication so that harmonious cooperation can be developed to achieve the goals (Baccal, 2005).

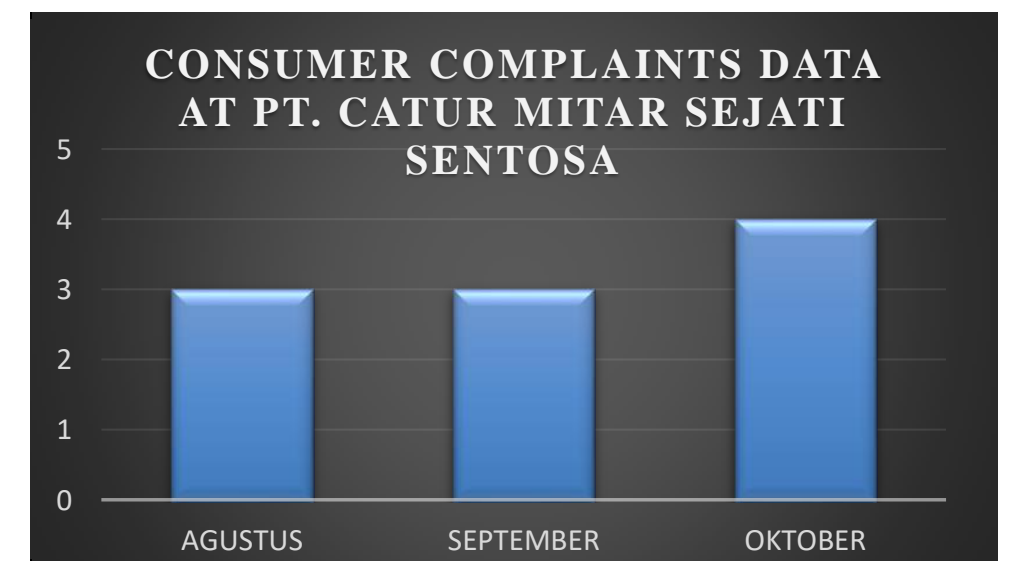

Figure 1. Consumer Complaints Data at PT. Catur Mitar Sejati Sentosa

Source: PT. Catur Mitra Sejati Sentosa (2020)

Work motivation for employees is also very important since it can encourage and train employees to do high-performance work based on company expectations. Even though the company has great competence employees, if the company cannot properly direct their potential, it is hardly to achieve the company's goals. Motivation is a condition in which one's efforts and willpower are directed towards achieving certain results or goals. The intended results can be seen in the form of productivity, attendance or other creative work behavior (Sopiah, 2008). Regarding motivation, it should lead to the desires of all employees, so that there is true alignment of motives between the company and its employees about how to work together to achieve the company's goals that have been set with the high performance. Thus, both parties can work effectively and optimally to develop and advance the company in the future.

Based on the description of the phenomenon above, the researcher is interested in conducting research regarding "The Effect of Work Communication and Work Motivation to Employee Performance at PT. Catur True Partners, Sentosa ".

\section{Literature Review}

According to Athoillah (2010) communication can be seen as a process. It means that communication is a flow of information through a series or sequence of several stages or steps that are dynamic. It is due to the fact that communication is a two-way process, not a one-way process. While the operational definition of communication is the quality of communication that exists between employees or between employees and superiors at PT. Catur Mitra Sejati Sentosa. 
The indicators employed in this research are cited from Athoillah (2010), among others:

1) The quality of communication between superiors and subordinates

2) The quality of communication between subordinates and superiors

3) The quality of communication between subordinates

4) Providing a positive influence

5) Familiarity

6) Increasing knowledge

7) Facilitating a problem solving

8) Equalizing perceptions

9) Exchanging experiences

Meanwhile, in accordance with Fathoni (2006), Motivation is a suggestion or encouragement which appears owing to the fact that it is given by someone to others or oneself. The encouragement is meant to change a person to be a better person. Motivation can also be interpreted as the reason for an action done by someone. The three main elements in this definition are intensity, direction and persistence.

1. Forms of Motivation

The following are forms of motivation often utilized by an organization or company, including:

a. Financial Compensation

One of the most often forms given to the work's achievement is compensation. The compensation provided by employees is usually in the form of money.

b. Direction and Control

Briefings are meant to determine for employees what they should do and what they shouldn't do.

c. Establishing effective work patterns

Effective adjustment of work patterns in increasing employee needs is not possible, at least in a large size, without implementing major changes in the internal culture of the company.

d. Policy

A policy can be defined as an action taken deliberately by management to influence the attitudes or feelings of employees. In other words, a policy is an attempt to create happiness among employees.

2. Types of Motivation

a. Intrinsic Motivation is motives that become active or works without external stimulation, since in every individual already has an urge to do something.

b. Extrinsic Motivation is motives that become active or works because of external stimulation.

The indicators employed in this research include:

a. Employment Relations

b. Work Environment

c. Praise at work

d. Salary earned

e. Yearly reward

According to Samsuddin (2018), employee performance is the level of success of employees in accomplishing their duties and responsibilities. Performance is basically what employees do and don't do. While the operational definition of employee performance itself is the level of employee performance at the Bank Jatim Branch of Dr. Soetomo Surabaya has a good performance cited from Samsuddin (2018) which is quoted from (Sedarmayanti, 2001) which includes:
a. Quality of work
b. Timing (promptness)
c. Initiative
d. Capability
e. Communication

The indicators applied in this research include:
a. Quality of work
b. Quality of service
c. Timing
d. Work accuracy
e. Initiative at work
f. Understanding the main duties and functions
g. Work ability 
h. Knowledge and skills

i. Work communication

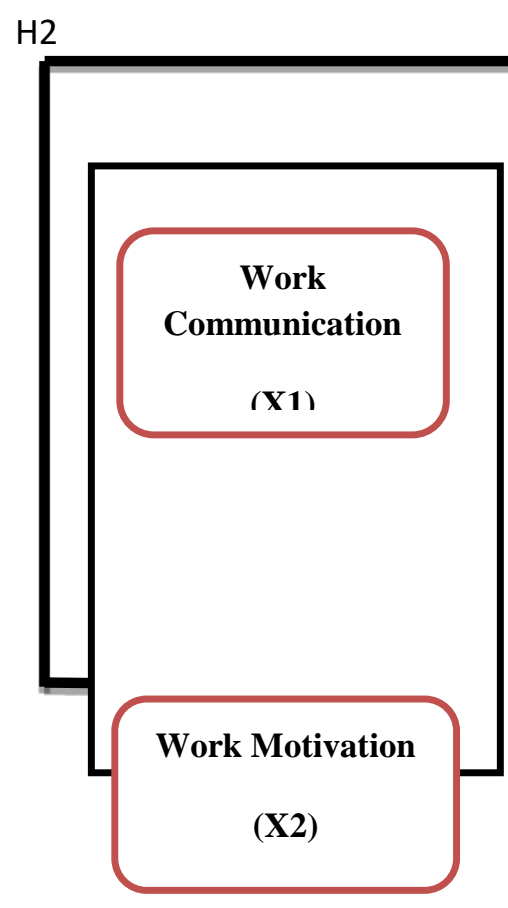

$\mathrm{H} 1$



Figure 2: Conceptual Thinking Framework Source : Author

\section{Methodology}

The type of this research is Explanatory Research, which objective is to clarify the connection between the research variables and examine the hypotheses that have been formulated with a quantitative approach. This research employed a survey method using a statement list instrument or a questionnaire as a data collection tool (Ferdinand, 2006). The scaling technique in this research uses the Likert scale.

A sample is part of the number and characteristics of the population Sugiyono (2018). The sampling technique in this research utilized saturated samples. Saturated sample means a sampling technique when all members of the population are used as samples Sugiyono (2018). Therefore, this research applies a sample of 65 people from all employees of PT. Catur Mitra Sejati Sentosa and all populations were taken as samples.

The validity test used correlation product moment, while the reliability test used Spearman Brown which processed by using SPSS 18.0 for Windows. Furthermore, the classical assumption test includes multicollinearity test and heteroscedasticity test. While the hypothesis testing in this research employs multiple regression analysis and the coefficient of determination as well as the hypothesis testing $t$ test and $\mathrm{f}$ test.

\section{Result and Discussion}

\subsection{Result}

\subsubsection{Validity Test}

The validity test is an extent that measures the existence characteristics of the phenomena in the research. According to R. (2007), the validity of an instrument is related to the ability of the instrument to measure or reveal the characteristics of the variable. Based on the questionnaire distributed to 65 respondents, the validity test was carried out using SPSS 18. In accordance with Ghozali (2011), the criteria utilized in determining the validity of the statements in this research were as follows:

1. The significance level is $5 \%$ or 0.05

2. Degree of freedom (df) $=n-2=65-2=63$, obtained $r_{\text {tabel }}=0,2441$ (value of $r_{\text {tabel }}$ for $n=65$ ).

3. If $r_{-}$count is greater than $r_{\text {table }}$ and the value of $r$ is positive, then the statement or question or indicator item is mean to be valid.

In line with the previous analysis, the validity test results can be shown as follows: 
Table 1 . The Validity Test Results

\begin{tabular}{|c|c|c|c|c|}
\hline No. & Indicators /Variables & $\begin{array}{c}\text { Corrected } \\
\text { Item-Total } \\
\text { Correlation }\end{array}$ & r Table & Decision \\
\hline & Work Communication & & & \\
\hline 1. & $\mathrm{X} 1.1$ & 0.666 & 0.244 & Valid \\
\hline 2. & $\mathrm{X} 1.2$ & 0.832 & 0.244 & Valid \\
\hline 3. & $\mathrm{X} 1.3$ & 0.436 & 0.244 & Valid \\
\hline 4. & $\mathrm{X} 1.4$ & 0.632 & 0.244 & Valid \\
\hline 5. & $\mathrm{X} 1.5$ & 0.779 & 0.244 & Valid \\
\hline 6. & X1.6 & 0.763 & 0.244 & Valid \\
\hline 7. & $\mathrm{X} 1.7$ & 0.790 & 0.244 & Valid \\
\hline 8. & $\mathrm{X} 1.8$ & 0.740 & 0.244 & Valid \\
\hline \multirow[t]{2}{*}{9.} & $\mathrm{X} 1.9$ & 0.601 & 0.244 & Valid \\
\hline & Work motivation & & & \\
\hline 1. & $\mathrm{X} 2.1$ & 0.828 & 0.244 & Valid \\
\hline 2. & $\mathrm{X} 2.2$ & 0.813 & 0.244 & Valid \\
\hline 3. & $\mathrm{X} 2.3$ & 0.823 & 0.244 & Valid \\
\hline 4. & X2.4 & 0.834 & 0.244 & Valid \\
\hline \multirow[t]{2}{*}{5.} & X2.5 & 0.766 & 0.244 & Valid \\
\hline & Employee performance & & & \\
\hline 1. & Y.1 & 0.797 & 0.244 & Valid \\
\hline 2. & Y.2 & 0.747 & 0.244 & Valid \\
\hline 3. & Y.3 & 0.889 & 0.244 & Valid \\
\hline 4. & Y.4 & 0.735 & 0.244 & Valid \\
\hline 5. & Y.5 & 0.562 & 0.244 & Valid \\
\hline 6. & Y.6 & 0.598 & 0.244 & Valid \\
\hline 7. & Y.7 & 0.545 & 0.244 & Valid \\
\hline 8. & Y.8 & 0.748 & 0.244 & Valid \\
\hline 9. & Y.9 & 0.889 & 0.244 & Valid \\
\hline
\end{tabular}

Table 1 reveals that all indicators utilized in measuring the variables of Work Communication (X1) Work Motivation (X2) Employee Performance (Y) used in this research have a correlation or $\mathrm{r}_{\text {count }}$ greater than $\mathrm{r}_{\text {table }}=$ $0.244\left(r_{\text {table }}\right.$ value for $\left.n=65\right)$ so that all indicators are valid.

\subsubsection{Reliability Test}

The reliability test is the extent in measuring consistency if the results are repeated in a characteristic. Reliability testing technique was carried out by using the reliability coefficient value of spearman Brown. The decision making criterion obtained if the Guttman Split-Half Coefficient value is more than 0.80.

Table 2. Variable of Reliability Test

\begin{tabular}{cccc}
\hline No. & Variables & Reliability Coefficient & Decision \\
\hline 1 & Communication (X1) & 0.803 & Reliabel \\
2 & Work Motivation (X2) & 0.807 & Reliabel \\
3 & Employee Performance (Y) & 0.802 & Reliabel \\
\hline
\end{tabular}

Source: Primary data processed by the author

According to the Table 2, it can be seen that the value of the Guttman Split-Half Coefficient for all variables is greater than 0.80 . From the provisions previously mentioned, all variables employed in this research are reliable. 


\subsubsection{Normality Test}

Before carrying out the normal distribution test, firstly, the value of each variable must be calculated. This value can be obtained by averaging the number of each variable indicator with a normal or nearly normal distribution.

As stated by Arifin (2008), the Normal Distribution Test is a distribution depicted in a bell-shaped graph, in the form of two symmetrical parts, starting from the left, rising up to a certain peak point then starting to decline but not touching the horizontal line of a data group is meant to have a normal distribution or normal function when it has the following characteristics:

1) Data can be calculated and data with extreme value (too big or too small) is not too much

2) The largest number of data that is close to the average value. Half of the data have a value less than or equal to the average value; and half have a value greater than or equal to the average value; and the other half have a value greater than or equal to the average value.

In general, it can be calculated by using the normal distribution test of Kolmogorov and Smirnov. The rule is that if the significant value is greater than 0.5 then the variable has a normal distribution.

Table 3. One-Sample Kolmogrov-Smimov Test

\begin{tabular}{ccc}
\hline & & $\begin{array}{c}\text { Unstandardized } \\
\text { Residual }\end{array}$ \\
\hline \multirow{2}{*}{ Normal Parameters ${ }^{\mathrm{a}, \mathrm{b}}$} & $\mathrm{N}$ & 65 \\
& & .0000000 \\
Most Extreme Differences & Mean & 2.53080690 \\
& Std. Deviation & .067 \\
& Absolute & .067 \\
& Positive & -.064 \\
& Negative & .541 \\
Kolmogorov-Smirnov Z & .932 \\
Asymp. Sig. (2-tailed) &
\end{tabular}

a. Test distribution is Normal.

b. Calculated from data.

From the calculation results obtained a sig. Value of 0.932 (can be seen in Table 3) or greater than 0.05 . Thus, the $\mathrm{H}_{\mathrm{o}}$ requirement is accepted since the normality assumption is fulfilled. For the P-P Plot test, it can be seen in Figure 3.

Normal P-P Plot of Regression Standardized Residual

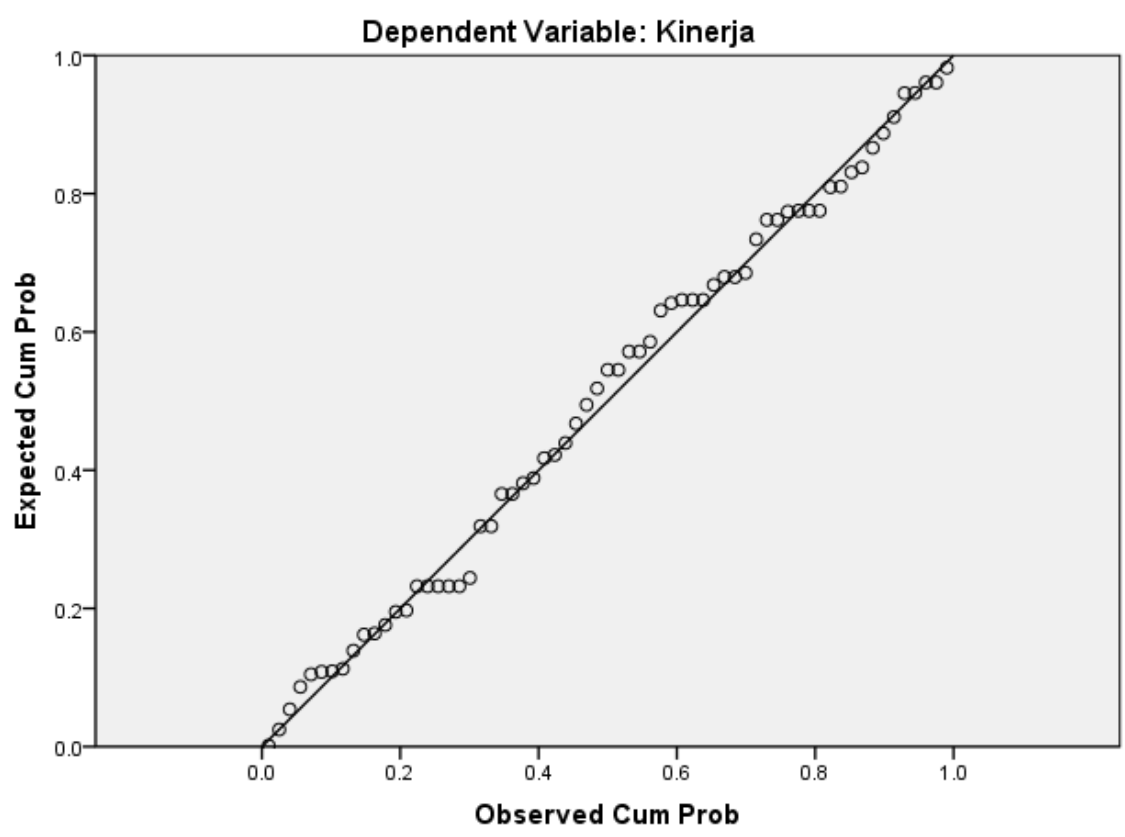

Figure 3. P-P Plot 


\section{JURNAL EKONOMI}

According to the P-P Plot test, it is appeared that the data points have spread along a diagonal line, therefore, it can be said that the variables of Work Communication (X1) Work Motivation (X2) Employee Performance (Y) is normally distributed.

\subsubsection{Multicollinearity Test}

Multicollinearity, is a circumstance in which the independent variable (independent) is correlated with other independent variables or an independent variable is a linear function of the other independent variables. A good regression model should not have a correlation between the independent variables (Ghozali, 2005).

Furthermore, the multicolonierity test in this research can be seen as follows:

Table 4. Multicollinearity Test

\begin{tabular}{|c|c|c|c|}
\hline & \multirow[b]{2}{*}{ Model } & \multicolumn{2}{|c|}{$\begin{array}{l}\text { Collinearity } \\
\text { Statistics }\end{array}$} \\
\hline & & $\begin{array}{c}\text { Tol } \\
\text { eran } \\
\text { ce }\end{array}$ & VIF \\
\hline \multirow[t]{3}{*}{1} & (Constant) & & \\
\hline & $\begin{array}{l}\text { Communication } \\
\text { (X1) }\end{array}$ & 439 & $\begin{array}{c}2.27 \\
7\end{array}$ \\
\hline & Motivation (X2) & 439 & $\begin{array}{c}2.27 \\
7\end{array}$ \\
\hline
\end{tabular}

a. Dependent Variable: Performance (Y)

The multicollinearity test results can be seen in Table 5 .

Table 5. Multicollinearity Test Results

\begin{tabular}{ccc}
\hline \multirow{2}{*}{ Independent variable } & \multicolumn{2}{c}{ Collinearity Statistics } \\
& Tolerance & VIF \\
\hline X1 & 0.439 & 2.277 \\
X2 & 0.439 & 2.277 \\
\hline Source: Primary data processed by the author
\end{tabular}

From the Table 5, it can be seen that the test results of each independent variable include:

a. Tolerance for Work Communication is 0.439

b. Tolerance for Work Motivation is 0.439

In the test results, it is discovered that the overall tolerance value is $>0.1$, so it can be concluded that there is no multicollinearity between the independent variables.

The multicollinearity test can also be done by comparing the VIF (Variance Inflation Factor) value with the number 10. If the VIF value $<10$, it means that there is no multicollinearity. Following are the test results for each independent variable:

a. The VIF for Work Communication is 2,277

b. The VIF for Work Motivation is 2,277

From the test results, it can be concluded that there is no multicollinearity between the independent variables. Thus, the assumption test for the absence of multicollinearity can be fulfilled.

\subsubsection{Heteroscedasticity Test}

The heteroscedasticity test objectifies to test whether there is a similarity in variance of the regression model from the residuals from one observation to another (Ghozali, 2005).

A good regression model refers to homoscedasticity or non heteroscedasticity (Ghozali, 2005). Basic analysis can be seen as follows:

1. If there is a certain pattern, such as the dots forming a certain regular pattern (wavy, widening then narrowing), it indicates that there is a heteroscedasticity.

2. If there is no clear pattern, as well as dots above and below the number 0 on the $\mathrm{Y}$ axis, then there is no heteroscedasticity. 


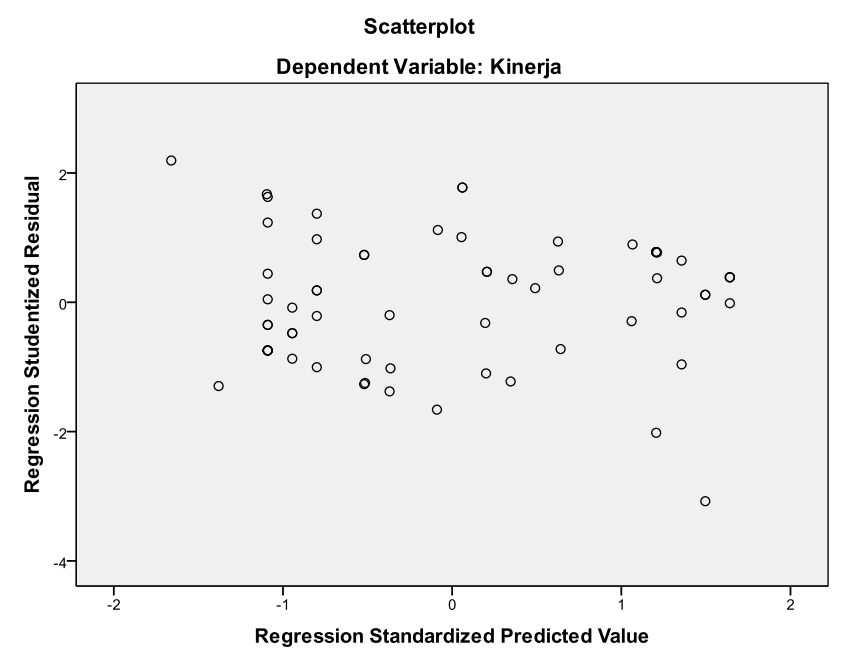

Figure 4. Scatterplot

Based on the Scatterplot graph in Figure 4, it appears that the dots spread randomly, either above or below zero on the $\mathrm{Y}$ axis. It can be concluded that the model in this research has met the requirements of homoscedasticity or without heteroscedasticity symptoms.

\subsubsection{Regression Equations}

The regression analysis is utilized to calculate the amount of influence between the independent variables, namely Work Communication (X1) and Work Motivation (X2) toward the dependent variable, so called Employee Performance ( $\mathrm{Y}$ ). The regression equation is used to determine the form of the relationship between the independent variable and the dependent variable. By using the SPSS for Windowsver 18.00, the regression model is obtained as in Table 5.

Table 6. Regression Equations

\begin{tabular}{|c|c|c|c|c|c|c|}
\hline & \multirow[t]{3}{*}{ Model } & \multicolumn{5}{|c|}{ Standardized } \\
\hline & & \multicolumn{2}{|c|}{ Unstandardized Coefficients } & \multicolumn{3}{|c|}{ Coefficients } \\
\hline & & B & Std. Error & Beta & $\mathrm{t}$ & Sig. \\
\hline \multirow[t]{3}{*}{1} & (Constant) & 13.273 & 3.934 & & 3.374 & .001 \\
\hline & $\begin{array}{l}\text { Communication } \\
\text { (X1) }\end{array}$ & .327 & .146 & .321 & 2.239 & .029 \\
\hline & Motivation (X2) & .642 & .236 & .390 & 2.724 & .008 \\
\hline
\end{tabular}

a. Dependent Variable: Performance (Y)

Source: Primary data processed by the author

According to the Table 5, the regression equation is obtained as follows:

$\mathrm{Y}=13,273+0.327 \mathrm{X} 1+0.642 \mathrm{X} 2$

From the equation above, it can be interpreted as follows:

a. A constant of 13,273 means that if work communication and work motivation are constant, the employee performance is 13,273 .

b. $\quad b 1=0.327$, means that employee performance will increase by 0.327 units for every additional unit of $\mathrm{X} 1$ (work communication). Therefore, if communication has increased by 1 unit, then employee performance will increase by 0.327 units, assuming the other variables are considered constant.

c. $\quad$ b2 $=0.642$, Employee Performance will increase by 0.642 units for every additional unit of $\mathrm{X}_{2}$ (Work Motivation). Therefore, if work motivation has increased by 1 unit, then Employee Performance will increase by 0.642 units, assuming the other variables are considered constant.

\subsubsection{Coefficient of Determination $\left(\mathbf{R}^{2}\right)$}

Based on Ghozali (2005), the coefficient of determination essentially measures how far a model is capable in explaining variations in the dependent variable. The coefficient of determination is zero and one. While, the small value of R2 means that the independent variables have provided all the information needed to predict the dependent variable. 
Table 7. Model Summary

\begin{tabular}{|c|c|c|c|c|}
\hline$\overline{\text { Model }}$ & $\mathrm{R}$ & R Square & $\begin{array}{l}\text { Adjusted } \\
\text { Square }\end{array}$ & $\begin{array}{l}\text { RStd. Error of the } \\
\text { Estimate }\end{array}$ \\
\hline$=1$ & $.665^{\mathrm{a}}$ & .442 & .424 & 2.571 \\
\hline
\end{tabular}

a. Predictors: (Constant), Motivation (X2), Communication (X1)

The coefficient of determination employed in this research is to calculate the effect or contribution of independent variables to the dependent variable. From the analysis in Table 6 , it is obtained the adjusted $\mathrm{R}^{2}$ (coefficient of determination) of 0.424 . This means that $42.4 \%$ of Purchase Decisions will be influenced by the independent variable, namely Work Communication (X1) Work Motivation (X2). While the remaining 57.6\% of the Purchasing Decision variable will be influenced by other variables which are not discussed in this research.

Instead of the coefficient of determination, the coefficient of correlation is also obtained which shows the magnitude of the relationship between the independent variables, namely Brand Ambassador, Product Quality and Sales Promotion with the Purchasing Decision variable, the R value (correlation coefficient) of 0.665 , this correlation value indicates that the relationship between the independent variables of Work Communication (X1 ) Work Motivation (X2) with Employee Performance (Y) is in the strong category because it is in the range of $0.6-0.8$.

\subsubsection{Simultaneous Test}

1. T Test

The t test according to Ghozali (2005) is applied to examine the significance level of the influence of the independent variables individually (partially) on the dependent variable (dependent) in implementing variations of the dependent variable. If the probability value $<0.05$ then the $t$ test can be obtained to partially predict the effect of the independent variable on the dependent variable. The significance of this effect can be estimated by comparing the table value and the calculated value.

1) If t-count $>\mathrm{t}$-table, or the level of significance $<0.05$, it appears that each independent variable partially has a significant effect on the dependent variable.

2) If t-count <t-table, or the level of significance $>0.05$, it appears that each independent variable partially does not have a significant effect on the dependent variable.

Table 8. Coefficients ${ }^{\mathrm{a}}$

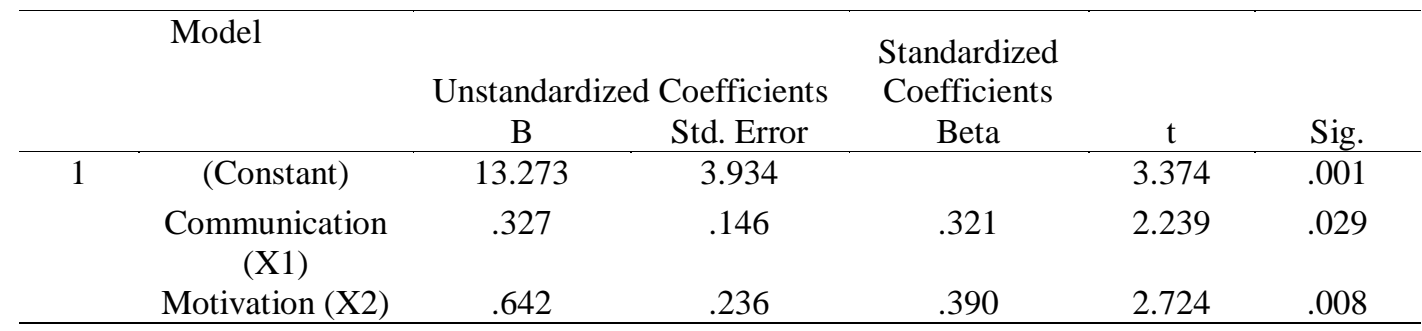

a. Dependent Variable: Performance (Y)

Based on the Table 7 above, it can be seen that the ${ }^{-}{ }_{\text {count }}$ value of the work communication variable (X1) is 2,239, and the work motivation variable (X2) is 2,724.

1) Testing on the effect of work discipline on employee performance.

The test results obtained that the $t$ count for the variable of work discipline on employee performance shows the value of $\mathrm{t}_{\text {count }}=2.239>$ from $\mathrm{t}_{\text {table }} 1.998$ with a significance of $0.029<0.05$ which means significant. Therefore, work communication variable partially has a positive and significant effect on employee performance.

2) Testing on the effect of work motivation on employee performance

The test results obtained from the $t_{-}$count value for the work motivation variable on the employee performance shows the value of $t_{\text {count }}=2.724>$ from $t_{\text {table }} 1.998$ with a significance of 
$0.008<0.05$, which means significant. Therefore, work motivation partially has a positive and significant effect on employee performance.

2. F Test

According to Ghozali (2005), F Test is a test to determine the effect of the independent variables, so called Work Communication (X1) Work Motivation (X2) simultaneously toward the dependent variable, so called Employee Performance (Y). The criteria for the hypothesis testing are as follows:

1) If F-count $>$ F-table, or the significance level $<0.05$, it means that each independent variable simultaneously has a significant effect on the dependent variable.

2) If F-count <F-table, or the level of significance> 0.05 , it means that each independent variable simultaneously does not have a significant effect on the dependent variable.

Table 9. ANOVA ${ }^{\mathrm{b}}$

\begin{tabular}{ccccccc}
\hline & Model & Sum of Squares & df & Mean Square & F & Sig. \\
\hline 1 & Regression & 324.635 & 2 & 162.317 & 24.550 & $.000^{\mathrm{a}}$ \\
& Residual & 409.919 & 62 & 6.612 & & \\
& Total & 734.554 & 64 & & & \\
\hline
\end{tabular}

a. Predictors: (Constant), Motivation (X2), Communication (X1)

b. Dependent Variable: Performance (Y)

Based on the data on the Table 8 above, it can be seen that $F_{-c o u n t}=24,550$ while the value of $F_{-t a b l e}$ is 3.996. Thus, $F_{\text {_count }}$ is $24.550>\mathrm{F}_{\text {table }}$ is 3.996 . In addition, the significant value of $0.000<0.05$, so it can be concluded that work communication (X1), work motivation (X2), simultaneously have a positive and significant effect on employee performance (Y) at PT. Catur Mitra Sejati Sentosa.

\subsection{Discussion}

In accordance with the research results, it is figured out that Work Communication (X1) Work Motivation (X2) have significant effects simultaneously on employee performance (Y). Thus, by increasing Work Communication (X1) Work motivation (X2), it can be concluded that it will also increase Employee Performance.

\section{Conclusion}

1. Based on the results, it is discovered that the variables of Work Communication (X1) Work Motivation (X2) have significant effects simultaneously on Employee Performance (Y). Thus, by increasing Work Communication (X1) Work Motivation (X2), it can be concluded that it will increase Employee Performance.

2. Based on the results of the t test partially, it is discovered that Work Communication (X1), partially brings a significant effect on Employee Performance.

3. Based on the results of the $t$ test partially, it is discovered that Work Motivation (X2), partially brings a significant effect on Employee Performance.

4. Based on the results of the $t$ test, it is discovered that the Work Motivation variable has the highest $t$ value and the beta coefficient. Thus, the Work Motivation variable has the strongest effect compared to other variables. Therefore, the Work Motivation variable has a dominant effect on Employee Performance.

\section{References}

Arifin, Z. (2008). Metodelogi Penelitan Pendidikan. Lentera Cendikia.

Athoillah, A. (2010). Dasar-Dasar Manajemen (B. A. Saebani (ed.)). CV Pustaka Setia.

Baccal, R. (2005). Performance Management. GM.

Fathoni, A. (2006). Manajemen Sumber Daya Manusia. Rineka Cipta.

Ferdinand, A. (2006). Metode Penelitian Manajemen: Pedoman Penelitian untuk skripsi, Tesis dan Disertai Ilmu Manajemen. Universitas Diponegoro.

Ghozali, I. (2005). Aplikasi Analisis Multivariate Dengan Program SPSS (Ketiga). Badan Penerbit Universitas Diponegoro.

Ghozali, I. (2011). Aplikasi Analisis Multivariate Dengan Program SPSS. Badan Penerbit Universitas Diponegoro.

Hasibuan, M. S. . (2002). Manajemen Sumber Daya Manusia. PT Bumi Aksara.

Irham, F. (2014). Analisa Kinerja Keuangan. Alfabeta. 


\section{JURNAL EKONOMI}

R., L. R. A. (2007). Riset pemasaran: teori dan praktik (R. Sikumbang (ed.)). Ghalia Indonesia. https://opac.perpusnas.go.id/DetailOpac.aspx?id=31244

Samsuddin, H. (2018). Kinerja Karyawan Tinjauan Dari Dimensi Gaya Kepemimpinan, Budaya Organisasi Dan Komitmen Organisasi (Pertama). indomedia pustaka.

Sedarmayanti. (2001). Sumber Daya Manusia dan Produktivitas Kerja. Mandar Maju.

Sopiah. (2008). Perilaku Organisasional. CV Andi Offset.

Sugiyono. (2018). Metode Penelitian Kuantitatif (Setiyamawi (ed.)). CV Alfabeta.

\section{Biography}

Elok Damayanti is a senior lecturer at the Faculty of Economic and Business Narotama University Surabaya. She received a Bachelor of Management degree from STIE Yapan Surabaya, and a Master of Management from Narotama University. Her research interests are in the field of Marketing and Human Resources Management.

Miftachul Choir, is a student at Narotama University, Faculty of Business Economics, majoring in Management. Born in the Surabaya city, exactly on Jl Deles 4/10 on December 6th, 1995. He worked on his undergraduate thesis in order to obtain a bachelor's degree. 